Int. J. Electrochem. Sci., 1(2006)99-109

International Journal of

ELECTROCHEMICAL

SCIENCE

www.electrochemsci.org

\title{
Anthraquinone-2-Carboxylic-Allyl Ester as a New Electrocatalyst for Dioxygen Reduction to Produce $\mathrm{H}_{2} \mathrm{O}_{2}$
}

\author{
Trevor Wilson ${ }^{1}$, Jiujun Zhang ${ }^{2, *}$, Colin C. Oloman ${ }^{1}$ and Danial D. M. Wayner ${ }^{3}$ \\ ${ }^{1}$ Department of Chemical Engineering, The University of British Columbia, Vancouver, British \\ Columbia, Canada V6T 1Z4 \\ ${ }^{2}$ Institute for Fuel Cell Innovation, National Research Council Canada, Vancouver, British Columbia, \\ Canada V6T 1W5 \\ ${ }^{3}$ Steacie Insitute for Molecular Sciences, National Research Council Canada, Ottawa, Ontario, Canada, \\ K1A 0R6 \\ *E-mail: jiujun.zhang@ @rc.gc.ca
}

Received: 31 May 2006/ Accepted: 5 June 2006/ Published: 8 June 2006

The irreversibly adsorbed anthraquinone-2-carboxylic-allyl ester (abbreviated as ACAE) on a graphite electrode displays strong electrocatalytical activity for the two-electron reduction of oxygen to form hydrogen peroxide. The surface electrochemistry of ACAE was examined by cyclic voltammetry. A two-electron, two-proton electrochemical redox process of the quinone group in the ACAE molecule was identified. A rotating disk electrode method was used to obtain the kinetic parameters of the electrocatalyzed reduction of oxygen. The high selectivity of ACAE for the two-electron reduction of oxygen in $\mathrm{pH}<7$ aqueous solution was demonstrated. The possible application of $\mathrm{ACAE}$ in $\mathrm{H}_{2} \mathrm{O}_{2}$ production is also explored in this paper.

Keywords: Oxygen reduction, Electro-catalysis, Anthraquinone-2-carboxylic-allyl ester, Graphite electrode, Hydrogen peroxide production

\section{INTRODUCTION}

Electrochemical production of hydrogen peroxide by the reduction of oxygen on carbon electrodes has been studied for many years [1-8]. In recent years, attention has been given to the electrocatalytical aspect of this process [8-11].

Various metal-complexes have been found to be effective electro-catalysts for dioxygen fourelectron reduction to $\mathrm{H}_{2} \mathrm{O}$, a reaction which can be potentially used in fuel cells [12-17]. However, our interest here is in the two-electron reduction from $\mathrm{O}_{2}$ to $\mathrm{H}_{2} \mathrm{O}_{2}$ for the purpose of $\mathrm{H}_{2} \mathrm{O}_{2}$ production. Our experiments with several metal-phthalocyanide complex coated graphite electrodes in $\mathrm{O}_{2}$ saturated 
aqueous solution have shown poor efficiency for $\mathrm{H}_{2} \mathrm{O}_{2}$ production, that is believed to be caused by the decomposition of the product $\mathrm{H}_{2} \mathrm{O}_{2}$ to $\mathrm{H}_{2} \mathrm{O}$ on the catalyst metal centers [8]. In recent years, the search has been shifted from metal-complex catalysts to anthraquinone-like organic compound [18-22]. In this paper, we are reporting a newly synthesized electrocatalyst in our laboratory, anthraquinone-2carboxylic-allyl ester (abbreviated as ACAE), which can strongly adsorb on the graphite electrode, and catalyze the two-electron reduction of oxygen to produce $\mathrm{H}_{2} \mathrm{O}_{2}$ with high current efficiency.

The electrocatalytical activity of quinone-like compounds toward the oxygen reduction has been studied widely [8-11] and the 9,10-anthraquinone derivatives have been reported to be effective catalysts for the electrochemical reduction of $\mathrm{O}_{2}$ to $\mathrm{H}_{2} \mathrm{O}_{2}$ on an illuminated semiconductive electrode [11], and the modified glass carbon electrodes [23, 24]. As reported here, the surface electrochemistry of ACAE on a graphite electrode was investigated and a two-electron, two-proton surface process was identified. A rotating disk electrode coated with ACAE was then used to examine the kinetics of the electrocatalytic reduction of oxygen to hydrogen peroxide.

\section{EXPERIMENTAL PART}

\subsection{Reagents and solutions}

The anthraquinone-2-carboxylic-allyl ester (Figure 1) was synthesized and purified according to the following procedure: Anthraquinone-2-carboxylic acid (Aldrich, 4g, $16 \mathrm{mmol}$ ) was dissolved in $50 \mathrm{ml}$ of thionyl chloride and refluxed in an oil bath for three hours. Excess thionyl chloride was removed by distillation and the yellow-green solid was dried under vacuum at room temperature for 30 minutes. The acid chloride was dissolved in $50 \mathrm{ml}$ of pyridine and cooled to $0^{\circ} \mathrm{C}$. Allyl alcohol $(1.2$ equivalents) was added dropwise and the solution was stirred at $0^{\circ} \mathrm{C}$ for 90 minutes. Once the reaction subsided, excess pyridine was distilled off and the light yellow product obtained was dried under vacuum then recrystallized from petroleum ether. The product was characterized by FTIR and confirmed that its chemical structure is as shown in Figure 1. Other reagent-grade chemicals were used without further purification. Water was purified by double distillation with $\mathrm{KMnO}_{4}$.

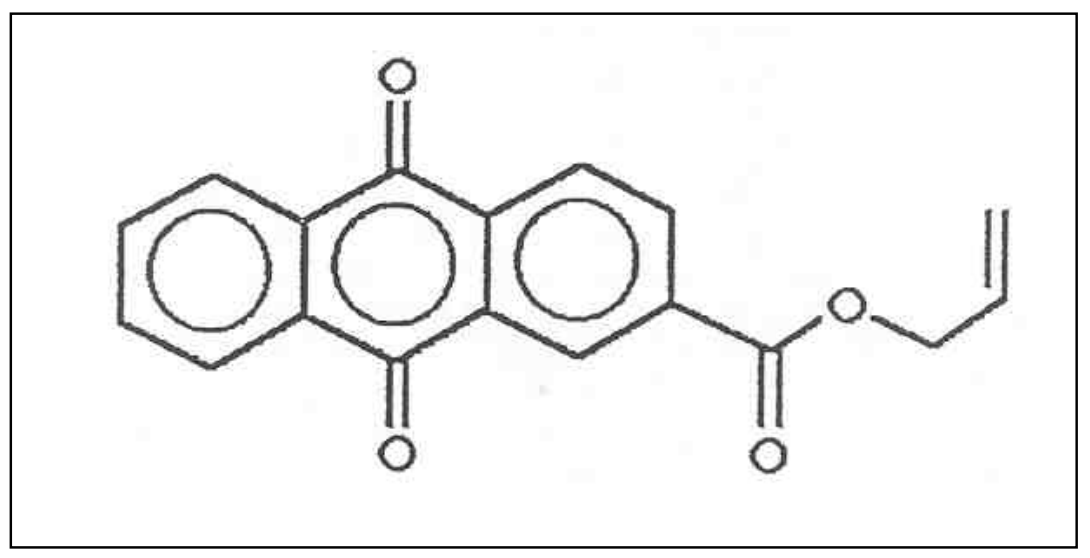

Figure 1. Structure of anthraquinone-2- carboxylic-allyl ester (abbreviated as ACAE). 
The solution $\mathrm{pH}$ was adjusted with $0.1 \mathrm{M}$ solution of $\mathrm{CH}_{3} \mathrm{COOH} / \mathrm{CH}_{3} \mathrm{COONa} / \mathrm{NaOH}$, and $0.1 \mathrm{M}$ $\mathrm{Na}_{2} \mathrm{SO}_{4}$ was used as supporting electrolyte. Pure nitrogen gas (99.9\%) was used to remove dissolved oxygen in the cyclic voltammetric experiments. In $\mathrm{O}_{2}$ reduction experiments, pure $\mathrm{O}_{2}(99.9 \%)$ gas was bubbled through the testing solution for 30 minutes before recording data.

\subsection{Electrode preparation}

The pyrolytic graphite (BPG, Union Carbide) disk electrode was sealed to a stainless steel shaft with polyolefin heat-shrinkable tubing. The electrode was mounted with the basal plane of the graphite exposed, and polished with $0.3 \mu \mathrm{m}$ alumina powder, sonicated in water for 5 minutes, then rinsed with acetone and water before each experiment. The area of the electrode, $0.14 \mathrm{~cm}^{2}$, was calibrated using a solution of $1 \times 10^{-3} \mathrm{M} \mathrm{K}_{3}\left[\mathrm{Fe}(\mathrm{CN})_{6}\right]$. In the long-term $\mathrm{H}_{2} \mathrm{O}_{2}$ production experiments, an electrode of area of $0.79 \mathrm{~cm}^{2}$ was used. The electrodes were modified by soaking a freshly polished electrode in a DMF solution saturated with ACAE for 3-30s, then washed with water and transferred into the testing solution to record electrodynamic data.

A platinum plate was used as a counter electrode, and a saturated calomel electrode was employed as the reference electrode.

\subsection{Apparatus}

Electrochemical measurements were performed with a conventional three-compartment cell and carried out with an RDE3 potentiostat, an electrode rotator (Pine Instruments) and an x-y recorder.

\subsection{Procedures}

For calculation of the diffusion-convection-limited current at rotating disk electrodes, the following parameters were employed [16, 17]: $\mathrm{D}_{\mathrm{o} 2}$ (the diffusion coefficient of $\mathrm{O}_{2}$ ) $=1.7 \times 10^{-5} \mathrm{~cm}^{2} \mathrm{~s}^{-1}$; kinematic viscosity of aqueous solutions $=0.01 \mathrm{~cm}^{2} \mathrm{~s}^{-1}$; concentration of $\mathrm{O}_{2}$ in its saturated aqueous solution $=1.3 \times 10^{-3} \mathrm{M}$.

For the measurements of the current efficiency of $\mathrm{O}_{2}$ reduction to $\mathrm{H}_{2} \mathrm{O}_{2}$, the standard iodometric $\mathrm{Na}_{2} \mathrm{~S}_{2} \mathrm{O}_{3}$ titration was used to analyze the concentration of $\mathrm{H}_{2} \mathrm{O}_{2}$ produced during the longterm run.

All experiments were carried out at ambient laboratory temperature and pressure (i.e. $22^{\circ} \mathrm{C}, 101$ $\mathrm{kPa}(\mathrm{abs}))$.

\section{RESULTS AND DISCUSSION}

\subsection{Surface electrochemistry of anthraquinone-2-carboxylic-allyl ester on a graphite electrode}

Figure 2 shows the surface cyclic voltammograms of a graphite electrode coated with $5.1 \times 10^{-10}$ mol.cm ${ }^{-2}$ of ACAE, recorded in a pure supporting electrolyte solution $\left(\mathrm{pH}=5.8\right.$, under $\mathrm{N}_{2}$, and without 


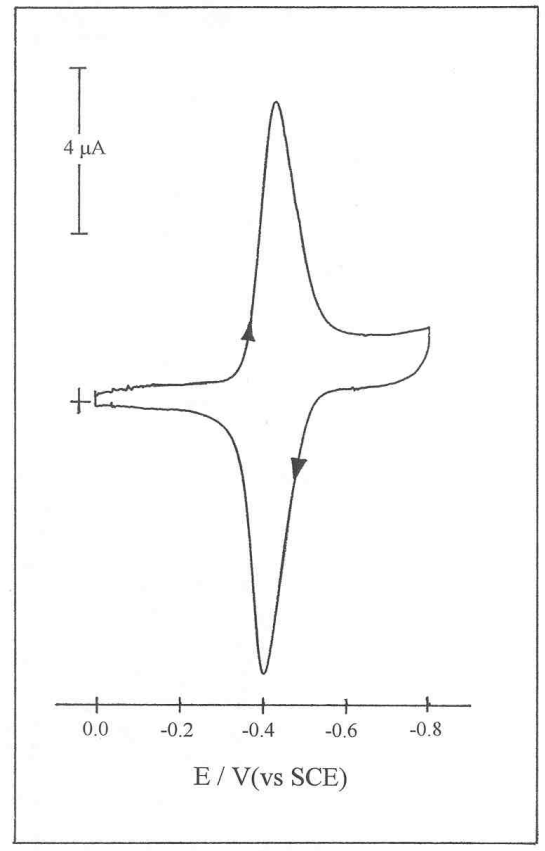

Figure 2. Cyclic voltammograms of a BPG surface adsorbed by $8.9 \times 10^{-10} \mathrm{~mol} . \mathrm{cm}^{-2}$ of ACAE in electrolyte: $0.1 \mathrm{M} \mathrm{Na}_{2} \mathrm{SO}_{4}+0.1 \mathrm{M}$ $\mathrm{CH}_{3} \mathrm{COOH} / \mathrm{CH}_{3} \mathrm{COONa}(\mathrm{pH}$ 5.8). Potential scan rate: $100 \mathrm{mV} . \mathrm{s}^{-1}$

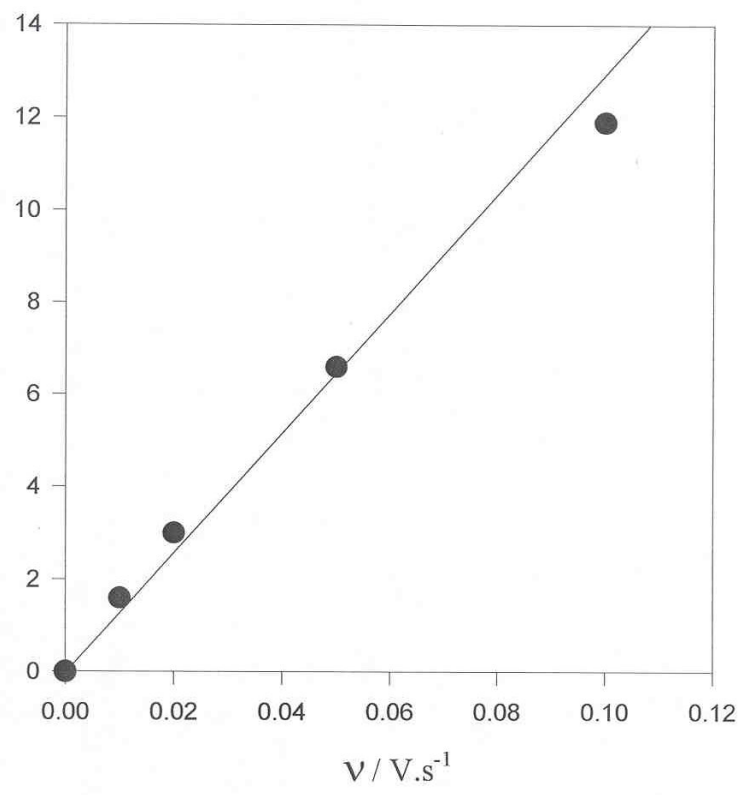

Figure 3. The scan rate dependence of the average of the anodic and cathodic peak currents on cyclic voltammograms as in Figure 2.

dissolved ACAE). A wave near $-0.4 \mathrm{~V}$ (vs. SCE, all potentials in this paper are relative to the potential of a saturated calomel electrode) can be observed. The measurement was carried out in a pure supporting electrolyte, therefore the current response of the wave near $-0.4 \mathrm{~V}$ only contains the contribution of adsorbed ACAE molecules. The average peak current, plotted as a function of potential scan rate, is shown in Figure 3. The linear relationship is typical of a surface confined electroactive reactant $[25,26]$.

Assuming that the wave near $-0.4 \mathrm{~V}$ is a reversible electrochemical process, equation (1) can be employed to estimate the electron number involved in the current response [25, 26]:

$\mathrm{i}_{\mathrm{p}}=\left(\mathrm{n}^{2} \mathrm{~F}^{2} v A \Gamma^{0}\right) /(4 \mathrm{RT})$

where $\mathrm{i}_{\mathrm{p}}$ (Amp) is the peak current, $\mathrm{n}$ the electron number involved in the response, $\mathrm{F}$ the Faraday's constant $\left(96487\right.$ C.mol $\left.{ }^{-1}\right), v$ the potential scan rate $\left(\mathrm{V} . \mathrm{s}^{-1}\right), \mathrm{A}$ the area of the electrode $\left(\mathrm{cm}^{2}\right), \Gamma^{0}$ the surface concentration of the adsorbed reactant $\left(\mathrm{mol} . \mathrm{cm}^{-2}\right), \mathrm{R}$ and $\mathrm{T}$ the common meanings. The electron number, $\mathrm{n}$ can be obtained if $\mathrm{i}_{\mathrm{p}}, \mathrm{F}, \mathrm{v}, \mathrm{A}, \Gamma^{\mathrm{o}}, \mathrm{R}$ and $\mathrm{T}$ are known. $\Gamma^{\mathrm{o}}$ was obtained by measuring the area under the current response wave near $-0.4 \mathrm{~V}$ in Figure 2, that is $5.1 \times 10^{-10} \mathrm{~mol} . \mathrm{cm}^{-2}$. The slope of the linear relationship between $i_{p}$ and potential scan rate in Figure 3 gives a value of 2.1 for the 
electron number (n), indicating a two-electron surface electrochemical process of ACAE on the graphite electrode.

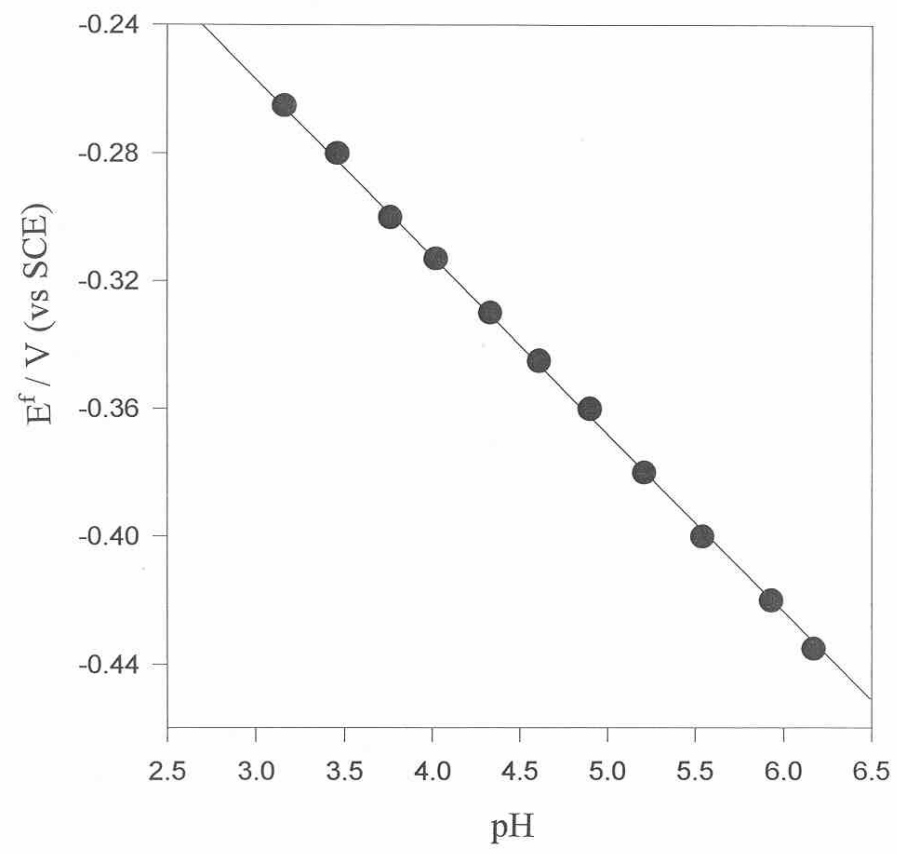

Figure 4. The $\mathrm{pH}$ dependence of the formal potential of the wave in Figure 2 estimated by averaging the anodic and cathodic peak potentials. Electrolytes as in Figure 2. Potential scan rate: $20 \mathrm{mV} . \mathrm{s}^{-1}$.

The formal potential of the electrochemical couple (wave near $-0.4 \mathrm{~V}$ in Figure 2) was estimated by averaging the anodic and cathodic peak potentials of the wave, and plotted as a function of solution $\mathrm{pH}$, as shown in Figure 4. A linear relationship with a slope of $57 \mathrm{mV} \cdot \mathrm{pH}^{-1}$ can be observed, indicating that the one proton per electron process is involved. For a two-electron process of the wave near $-0.4 \mathrm{~V}$ (Figure 2), indicated by Figure 3, two protons are involved. Therefore the response indicated by wave near - $0.4 \mathrm{~V}$ (Figure 2) is a two-electron, two proton electrochemical process. This response can be assigned to a well-known redox process of the anthraquinone group [17, 27-30] in the ACAE molecule:<smiles>C=CCOC(=O)c1ccc2c(O)c3cc(C(C)C)ccc3c(O)c2c1</smiles>

The attachment of adsorbed ACAE coating on the graphite electrode is stable. The coated electrode can be scanned between 0 and $-0.8 \mathrm{~V}$ in a $\mathrm{pH} 5.6$ solution for 4 hours without apparent decrease in the magnitude of the peak current of the wave near $-0.4 \mathrm{~V}$. 


\subsection{Electrocatalytic activity of adsorbed ACAE toward the reduction of $\mathrm{O}_{2}$ to $\mathrm{H}_{2} \mathrm{O}_{2}$}

The ACAE coated graphite electrode was examined in an oxygen saturated solution (under oxygen at $101 \mathrm{kPa}(\mathrm{abs})$ ) by cyclic voltammetry, with typical results as shown in Figure 5B.

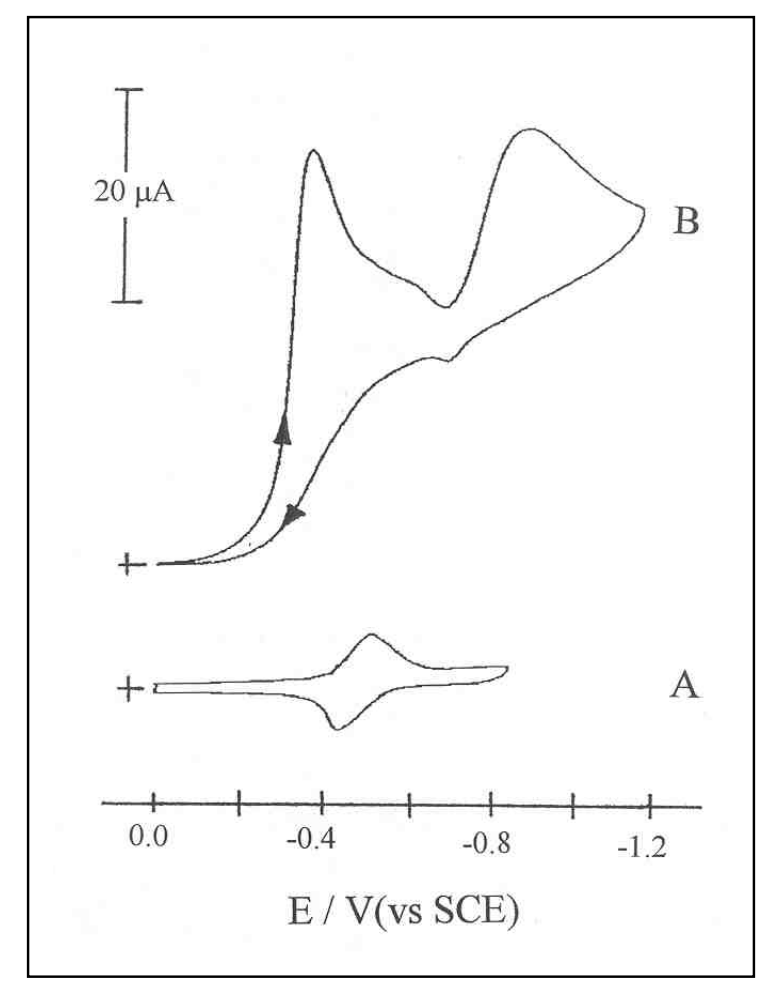

Figure 5. Cyclic voltammograms of a BPG electrode coated with $9.0 \times 10^{-10} \mathrm{~mol} . \mathrm{cm}^{-2}$ of ACAE in pure supporting electrolyte (a), and $1.3 \times 10^{-3} \mathrm{M}_{\text {of }} \mathrm{O}_{2}$ (b). Supporting electrolyte as in Figure 2 (pH 5.6). Potential scan rate: $10 \mathrm{mV} \cdot \mathrm{s}^{-1}$.

The peak near $-0.45 \mathrm{~V}$ is believed to be a two-electron process of $\mathrm{O}_{2}$ reduction to $\mathrm{H}_{2} \mathrm{O}_{2}$. The second peak near $-0.87 \mathrm{~V}$ is a two-electron process of reduction of $\mathrm{H}_{2} \mathrm{O}_{2}$, produced during the wave at $-0.45 \mathrm{~V}$, to $\mathrm{H}_{2} \mathrm{O}$. This second reduction was confirmed by the following experiment. In the same conditions as those in Figure $5 \mathrm{~B}, \mathrm{H}_{2} \mathrm{O}_{2}$ was added into the solution, then the cyclic voltammograms were recorded. The proportional increase with added $\mathrm{H}_{2} \mathrm{O}_{2}$ in the magnitude of the peak current near $-0.87 \mathrm{~V}$ could be observed, while the first peak current near $-0.45 \mathrm{~V}$ remained unchanged. The second process from $\mathrm{H}_{2} \mathrm{O}_{2}$ to $\mathrm{H}_{2} \mathrm{O}$ is not our special interest, so no further investigation was pursued here. A bare graphite electrode was also tested in the same solution as that of Figure 5B (the CV is not shown here). Two waves which are similar to Figure 5B but with poor peak separation can also be observed. However, the recorded currents for both waves are approximately half of those recorded in the presence of adsorbed ACAE, and this demonstrates the catalytic activity of ACAE. The potential position of twoelectron reduction from $\mathrm{O}_{2}$ to $\mathrm{H}_{2} \mathrm{O}_{2}$ (first wave in Figure 5B) commences near the potential where the 
reduction of ACAE occurs (Figure 5A), indicating that the electrocatalytic $\mathrm{O}_{2}$ reduction process does involve the ACAE red/ox couple.

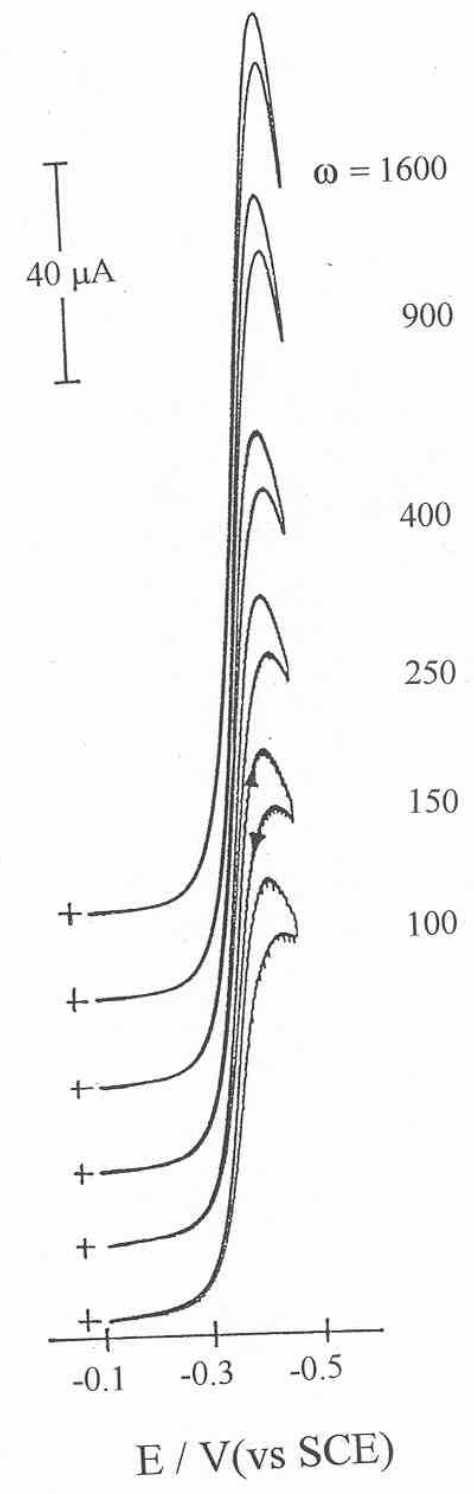

Figure 6. Electroreduction of $1.3 \times 10^{-3} \mathrm{M} \mathrm{O}_{2}$ on a rotating BPG electrode coated with $1.0 \times 10^{-9} \mathrm{~mol}^{-\mathrm{cm}^{-}}$ 2 of ACAE. The electrode rotating rates: (a) $100 \mathrm{rpm}$; (b) $150 \mathrm{rpm}$ ); (c) $250 \mathrm{rpm}$; (d) $400 \mathrm{rpm}$; (e) 900 $\mathrm{rpm}$; and (f) $1600 \mathrm{rpm}$. Supporting electrolyte as in Figure 1 (pH5.6). Potential scan rate: $10 \mathrm{mV} \cdot \mathrm{s}^{-1}$.

For the quantitative assesment of the catalytic activity, the $\mathrm{O}_{2}$ reduction was measured at a rotating disk electrode on which the ACAE had been irreversibly adsorbed. A set of typical current- 
potential curves for the reduction of $\mathrm{O}_{2}$ is shown in Figure 6. The current-potential curves exhibit maxima rather than true plateau currents. The decrease in the magnitude of the catalytic current after the maximum diffusion current may reflect the change in chemical nature or structure of the catalyst during the reduction of the substrate $[31,32]$. The process is reversible since similar behaviour can be observed if the potential scan is reversed. The Levich and Koutecky-Levich theories [33, 34] were employed approximately here to describe quantitatively the electrocatalytic $\mathrm{O}_{2}$ reduction. The representative Koutecky-Levich plots are shown in Figure 7.

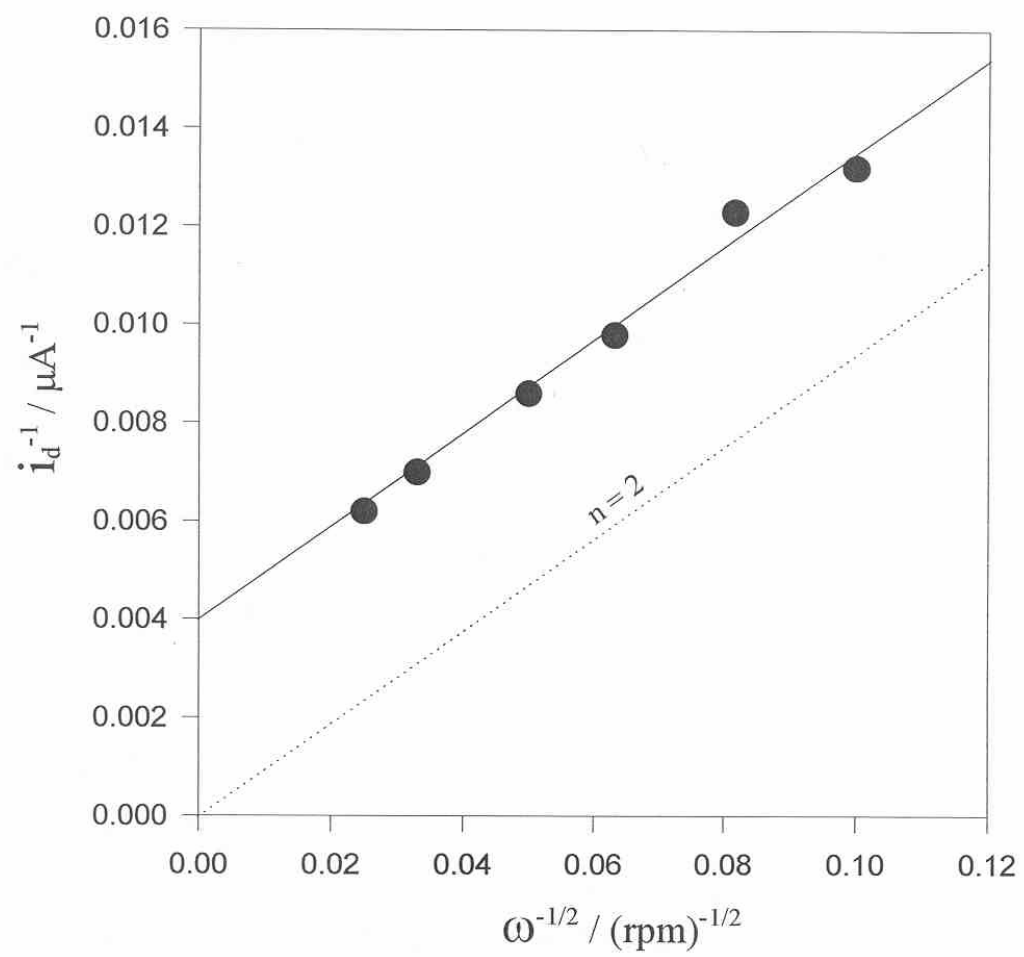

Figure 7. Koutecky-Levich plot for data in Figure 6. The dashed line corresponds to the calculated response for the diffusion-convection-controlled curve for two-electron reduction of $\mathrm{O}_{2}$.

The slope of the measured plot (Figure 7, solid line) is nearly parallel to that calculated (Figure 7, dashed line) for the two-electron reduction of $\mathrm{O}_{2}$, confirming the result of the two-electron transfer process discussed for Figure 5. The reciprocal intercept of the Koutecky-Levich plot can give a kinetic current $\left(\mathrm{i}_{\mathrm{k}}\right)_{\mathrm{O}_{2}}$, which may be defined in equation (3) [25]:

$\left(\mathrm{i}_{\mathrm{k}}\right)_{\mathrm{O}_{2}}=\mathrm{nFAk}_{\mathrm{O}_{2}} \Gamma_{\mathrm{ACAE}} \mathrm{C}_{\mathrm{O}_{2}}$

where $\mathrm{n}, \mathrm{F}$, and $\mathrm{A}$ are the same meanings as in equation (1), $\mathrm{k}_{\mathrm{O}_{2}}$ is the rate constant of the currentlimiting reaction $\left(\mathrm{M}^{-1} \cdot \mathrm{s}^{-1}\right), \Gamma_{\mathrm{ACAE}}$ is the surface concentration of catalyst $\left(\mathrm{mol} . \mathrm{cm}^{-2}\right)$, and $\mathrm{C}_{\mathrm{O}_{2}}$ is the bulk concentration of $\mathrm{O}_{2}\left(\mathrm{~mol} . \mathrm{cm}^{-3}\right)$. For example, in an $\mathrm{O}_{2}$ saturated solution $\left(\mathrm{C}_{\mathrm{O}_{2}}=1.3 \times 10^{-6}\right.$ mol.cm $\left.{ }^{-3}\right)$, the obtained rate constant is $8.4 \times 10^{3} \mathrm{M}^{-1} \cdot \mathrm{s}^{-1}$ on an ACAE coated graphite electrode $\left(\Gamma_{\mathrm{ACAE}}=8.9 \times 10^{-10} \mathrm{~mol} . \mathrm{cm}^{-2}\right)$. 
Experiments with different quantities of ACAE adsorbed on the electrode showed the approximately linear dependence of $\left(\mathrm{i}_{\mathrm{k}}\right)_{\mathrm{O}_{2}}$ on $\Gamma_{\mathrm{ACAE}}$ when $\Gamma_{\mathrm{ACAE}}$ is less than $1.0 \times 10^{-9} \mathrm{~mol} . \mathrm{cm}^{-2}$, While if the quantity of catalyst is in excess of $1.1 \times 10^{-9} \mathrm{~mol}^{-\mathrm{cm}^{-2}}$, the $\left(\mathrm{i}_{\mathrm{k}}\right)_{\mathrm{O}_{2}}$ becomes almost independent of $\Gamma_{\mathrm{ACAE}}$, indicating that only those catalyst molecules in direct contact with or near the electrode surface participate in the catalytic cycle. Another factor is that at higher coverage, $\mathrm{O}_{2}$ permeation through the adsorption layer and/or electron propagation within the layer may become a rate limiting step [35], that can also cause the $\left(\mathrm{i}_{\mathrm{k}}\right)_{\mathrm{O}_{2}}$ independent behaviour.

Values of $\left(\mathrm{i}_{\mathrm{k}}\right)_{\mathrm{O}_{2}}$ were obtained with various concentrations of $\mathrm{O}_{2}$, and a linear relationship between $\left(\mathrm{i}_{\mathrm{k}}\right)_{\mathrm{O}_{2}}$ and $\mathrm{C}_{\mathrm{O}_{2}}$ was observed in the $\mathrm{O}_{2}$ concentration range of $1 \times 10^{-4}-1.3 \times 10^{-3} \mathrm{M}$, which confirms that equation (3) is probably a suitable model for describing the kinetic behaviour of the electrocatalytic reduction of $\mathrm{O}_{2}$.

\subsection{A mechanistic comment}

As indicated in Figure 5, the reduction of $\mathrm{O}_{2}$ to form $\mathrm{H}_{2} \mathrm{O}_{2}$ occurs at approximately the same potential as that of the ACAE couple, providing reasonable evidence that the reduced ACAE (twoelectron and two-proton process) is the actual reductant, which is confined to the electrode surface and promotes the catalytic process for $\mathrm{O}_{2}$ reduction. The catalytic reduction of $\mathrm{O}_{2}$ here is believed to be through an outer-sphere mechanism because it is unlikely for a non metal-complex catalyst (such as ACAE) to perform via an inner-sphere mechanism [36, 37].

For the reduction of $\mathrm{O}_{2}$ catalyzed by surface ACAE, the first step should be the surface reduction of ACAE, as described by Equation (2), to form surface species of $\mathrm{H}_{2} \mathrm{ACAE}$. The followed electron transfer from $\mathrm{H}_{2} \mathrm{ACAE}$ to $\mathrm{O}_{2}$ can be described by Equation (4):

$\mathrm{O}_{2}+\mathrm{H}_{2} \mathrm{ACAE}=====>\mathrm{H}_{2} \mathrm{O}_{2}+\mathrm{ACAE}$

Since one of the products is the regenerated ACAE, the process is electrocatalytic. Actually, the mechanism may not be as simple as described by reactions (2) and (4). More detailed assessment of the mechanism would be the further work.

\subsection{Long-term $\mathrm{H}_{2} \mathrm{O}_{2}$ production}

A rotating graphite disk electrode $\left(0.79 \mathrm{~cm}^{2}\right.$, rotated at $\left.400 \mathrm{rpm}\right)$ coated with $1.1 \times 10^{-9}$ mol.cm $\mathrm{cm}^{-2}$ of ACAE was employed in an $\mathrm{O}_{2}$ saturated solution (under $101 \mathrm{kPa}(\mathrm{abs})$ oxygen pressure, $\mathrm{pH}=5.6$, $200 \mathrm{ml}$ ) to examine the long-term production of $\mathrm{H}_{2} \mathrm{O}_{2}$. The result of a three-day run is shown in Figure 8. The current efficiency for $\mathrm{H}_{2} \mathrm{O}_{2}$ drops gradually with time from $97 \%$ to $74 \%$ as the $\mathrm{H}_{2} \mathrm{O}_{2}$ concentration increases from 0 to $3.8 \mathrm{mM}$. The same electrode but without ACAE coating was also tested in the same conditions, a low current efficiency for $\mathrm{H}_{2} \mathrm{O}_{2}$ (the concentration of $\mathrm{H}_{2} \mathrm{O}_{2}$ was from 0 to $0.4 \mathrm{mM}$ ) was observed, which suggests the utility of a catalyst such as ACAE for the electrosynthesis of peroxide especially in weak acidic solution. 


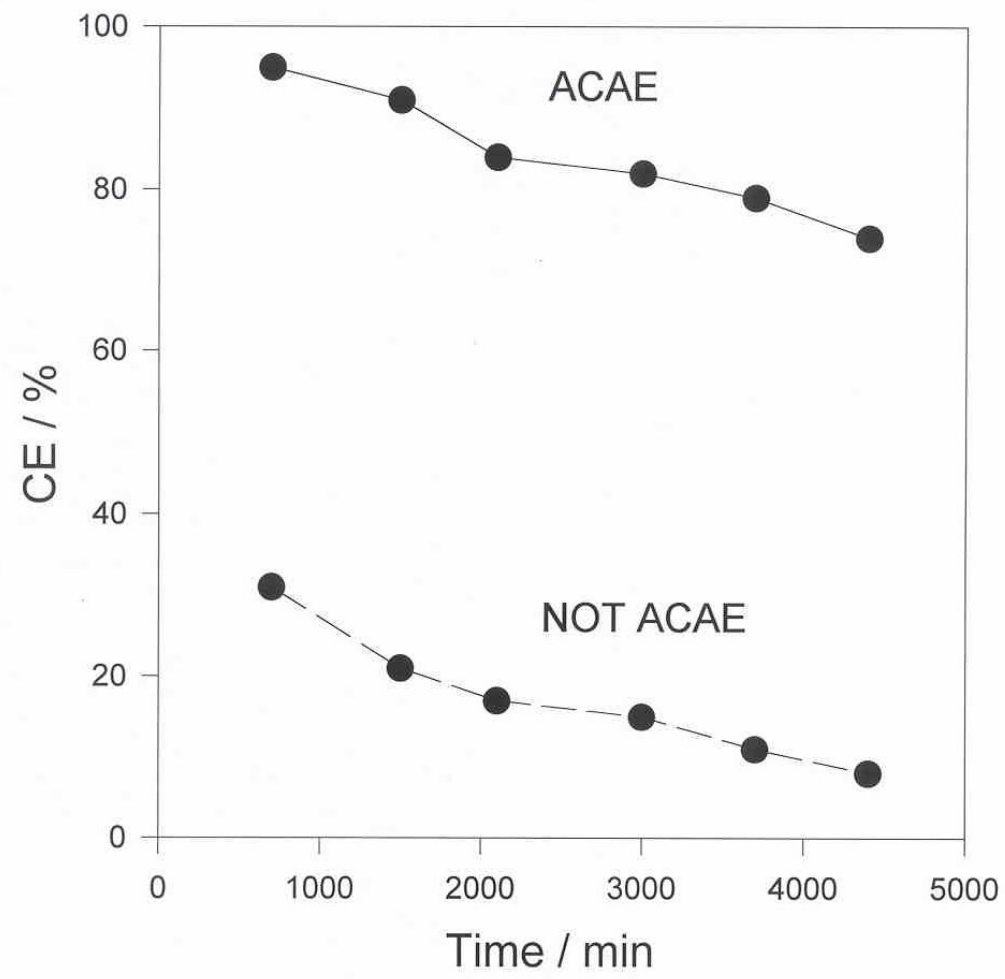

Figure 8. The current efficiencies of a three-day run. The data were obtained with a BPG electrode $\left(0.79 \mathrm{~cm}^{2}\right)$ coated with $1.1 \times 10^{-9} \mathrm{~mol} . \mathrm{cm}^{-2}$ of ACAE (upper curve), and the same electrode but without catalyst (bottom curve), rotated at $400 \mathrm{rpm}$, in $1.3 \times 10^{-3} \mathrm{M} \mathrm{O}_{2}$ solution (pH5.6). Supporting electrolyte as in Figure 2. Current density of electrolysis: $160 \mu \mathrm{A} \cdot \mathrm{cm}^{-2}$.

\section{CONCLUSIONS}

Anthraquinone-2-Carboxylic-Allyl Ester (ACAE) is found to be electrocatalytically active toward the two-electron reduction of $\mathrm{O}_{2}$ to produce $\mathrm{H}_{2} \mathrm{O}_{2}$. The surface cyclic voltammetry reveals the twoelectron, two-proton process of this catalyst, which probably involves an outer-sphere mechanism to catalyze $\mathrm{O}_{2}$ reduction. The kinetics of this electrocatalytic reduction of $\mathrm{O}_{2}$ are examined on an ACAE coated rotating graphite electrode, to show a rate constant of $8.4 \times 10^{3} \mathrm{M}^{-1} \cdot \mathrm{s}^{-1}$ at $22^{\circ} \mathrm{C}$.

The stability of ACAE together with its high selectivity for catalytic reduction from $\mathrm{O}_{2}$ to $\mathrm{H}_{2} \mathrm{O}_{2}$ may make it feasible to employ this modified electrode for $\mathrm{H}_{2} \mathrm{O}_{2}$ production in weak acidic solutions.

\section{ACKNOWLEDGMENT}

This research work was funded by the Mechanical and Chemimechanical Pulps Network (one of fifteen Networks of Centres of Excellence sopported by the Government of Canada) and was supported by Paprican,the University of British Columbia, and National Research Council Canada. Discussion with Dr.Yu-Hong Tse is gratefully acknowledged. 


\section{References}

1. C. Oloman, and A. P. Watkinson, Can. J. Chem. Eng., 53(1975)268

2. E. Yeager, P. Krouse, and K. V. Rao, Electrochim. Acta, 9(1964)1057

3. C. Oloman, and A. P. Watkinson, Can J. Chem. Eng., 54(1976)312

4. R. Alkire, and P. Ng, J. Electrochem. Soc., 121(1974)1\&95

5. C. Oloman, and A. P. Watkinson, J. Appl. Electrochem., 9(1979)117

6. M. S. Wrighton, Science, 231(1986)32

7. C. Oloman, "Electrochemical Processing For the Pulp and Paper industry", The Electrochemical Consultancy, Romsey (1996).

8. Y. H. Tse and C. Oloman, unpublished work, 1995

9. G. S. Calabrese, R. M. Buchanan, and M. S. Wrighton, J. Am. Chem. Soc., 105(1983)5594

10. E. Katz, and H. L. Schmidit, J. Electroanal. Chem., 368(1994)87

11. B. Keita, and L. Najdo, J. Electroanal. Chem., 145(1983)431

12. T. Kuwana, M. Fujihara, K. Sunakawa, and T. Osa., J. Electroanal. Chem., 88(1978)229

13. C. Shi, and F. C. Anson, Inorg. Chem., 29(1990)4305

14. J. P. Collman, P. Denisevich, Y. Konai, M. Marrocco, C. Koval, and F. C. Anson, J. Am. Chem. Soc., 102(1980)6027

15. S. Zecevic, B. Simic-Glavaski, E. Yeager, A. B. P. Lever, and P. C. Minor, J. Electroanal. Chem., 196(1985)339

16. J. J. Zhang, and F. C. Anson, Electrochim. Acta, 38(1993)2423

17. J. J. Zhang, and F. C. Anson, J. Electroanal. Chem., 353(1993)265

18. A. Huissoud, and P. Tissot, J. Appl. Electrochem., 28(1997)653

19. A. Huissoud, and P. Tissot, J. Appl. Electrochem., 29(1998)11

20. A. Huissoud, and P. Tissot, J. Appl. Electrochem., 29(1998)17

21. E. L. Gyenge, and C. W. Oloman, J. Appl. Electrochem., 33(2003)655

22. E. L. Gyenge, and C. W. Oloman, J. Appl. Electrochem., 33(2003)665

23. A. Salimi, H. Eshghi, H. Sharghi, S. M. Golabi, and M. Shamsipur, Electroanalysis, 11(2), (1999) 114

24. K. Tammeveski, K. Kontturi, R. J. Nichols, R. J. Potter, and D. J. Schiffrin, J. Electroanal. Chem., 515(2001)101

25. A. B. Brown, and F. C. Anson, Anal. Chem., 49(1977)1589

26. A. J. Bard, and L. R. Faulkner, Electrochemical Methods, Fundamentals and Applications, John Wiley Sons, New York, 1980

27. T. Ohsaka, N. Oyama, Y. Takashira, and S. Nakamura, J. Electroanal. Chem., 247(1988)339

28. J. J. Zhang, and F. C. Anson, J. Electroanal. Chem., 331(1992)945

29. J. J. Zhang, A. B. P. Lever, and W. J. Pietro, Inorg. Chem., 33(1994)1392

30. J. J. Zhang, A. B. P. Lever, and W. J. Pietro, J. Electroanal. Chem., 385(1995)191

31. J. J. Zhang, and F. C. Anson, J. Electroanal. Chem., 341(1992)323

32. J. J. Zhang, Y. H. Tse, W. J. Pietro, and A. B. P. Lever, J. Electroanal. Chem., in press

33. J. Koutecky and V. G. Levich, Zh. Fiz. Khim, 32(1958)1565

34. V. G. Levich, Physicochemical Hydrodynamics, Prentice Hall, Englewood Cliffs, New Jersey, (1962)345

35. C. Lin, and A. B. Bocarsly, J. Electroanal. Chem., 300(1991)325

36. C. P. Andrieux, J. M. Dumas-Bouchiat and J. -M Saveant, J. Electroanal. Chem., 123(1981)171

37. R. Jiang, and F. C. Anson, J. Electroanal. Chem., 305(1991)171

(C) 2006 by ESG (www.electrochemsci.org) 